\title{
Chlorogenic Acid Isolation from Coffee as Affected by the Homogeneity of Cherry Maturity
}

\author{
Husniati Husniati ${ }^{1 *}$ and Devi Oktiani ${ }^{1)}$ \\ ${ }^{1)}$ Center for Research and Standardization of Industry in Bandar Lampung - Ministry of Industry, Indonesia \\ ${ }^{*}$ Corresponding author: husniati@kemenperin.go.id \\ Received: 14 March 2019 / Accepted: 21 June 2019
}

\begin{abstract}
Chlorogenic acid is a polyphenol compound which has an antioxidant properties. The objectives of this research are to understand and compare the characteristics of caffeine, chlorogenic acid, and polyphenolic content in Robusta coffee treated differently. These are necessary to find out effective postharvest method for chlorogenic acid extraction. There were two group of samples with the different treatment in process and post harvests. The coffee was treated differently during the sortation and classified into selected coffee of red cherry (fully mature cherry) and unselected coffee (partly mature cherry). The sortation was to maximize the chlorogenic acid content in green coffee bean sample from red cherry bean as the raw material. This research found that the contents of chlorogenic acid extract of green coffee bean from the selected red cherry was higher than the unselected. The HPLC analysis for chlorogenic acid contents of green coffee bean from the selected red cherry was $4.41 \%$, it was higher than other samples tested.
\end{abstract}

Keywords: Cholorogenic acid, coffee bean, sortation, Robusta

\section{INTRODUCTION}

Coffee distributors in Indonesia are interested to buy all quality of coffee. There is no additional price or incentives for good quality coffee (Handayani, 2015). The price of coffee without selection and classification at the farm level is low (Ramanda et al., 2016). Farmers tend to do harvest not only during the harvest season. The unselected coffee is produced by farmers without selection and classification, while the selected coffee is coffee which is selected based on red cherry color. The reason of unselected harvest is saving cost and energy (Sudaryanto et al., 2016).

The post-harvest treatment has an effect on coffee quality. Therefore, it is necessary to select the appropriate post-harvest process in producing coffee powder or extract based on the product characteristics to be made. The harvest is done in several stages. The farmers pick the coffee based on fruit ripeness, the harvest periods are vary from 2-4 times a year depend on the fruit ripeness (Ramanda et al., 2016). The first stage is preliminary picking for pre-riped fruits (Teniro et al., 2018). The coffee should be harvested when the color is red, the red color indicates the level of ripeness. However, farmers pick coffee fruit on various condition, they pick the unselected (various colors) and red (selected) picking. Although farmers apply red picking, the picking method is not optimal because the percentage of red fruit is only about 70\% (Aklimawati et al., 2014). 
The purpose of selection is to separate between the ripen cherries and the defective cherries, broken, not uniform in size or attacked by pests and diseases. Coffee are carefully sorted based on quality (defective, black, broken, hollow, and attacked by pests (Ramanda et al., 2016).

One of active compound in coffee is chloregenic acid. It is produced from coffee by extraction (Sukohar \& Muhartono, 2015). It has antioxidant and anticancer benefits (Kajikawa et al., 2018; Liang \& Kitts, 2016; Maalik et al., 2016; Naveed, 2018; Tajik et al., 2017; Sukohar \& Muhartono, 2015). It is not only good for health, but also affects the taste and aroma (Taveira et al., 2015). Chlorogenic acid in green coffee is higher than in roasted coffee (Cuong et al., 2014), however decrease due to the heating process (Jeszka-Skowron et al., 2016). The postharvest period also has effect on variation on chlorogenic acids contents (Kouadio et al., 2014).

\section{MATERIALS AND METHODS}

Red coffee cherries (selected) were obtained from smallholder applying organic fertilizer in Pesawaran, Lampung and supplied by PT. Ghaly Rolies. Unselected coffee is harvested from farmers in the Ulubelu area of Tanggamus from a commercial coffee supplyer. All the coffee trees are classified as Robusta coffee.

This research compares different samples of coffee from different maturity level and then analyze the caffeine and chlorogenic acid contents of each sample. The wet process of green coffee bean production are hulling of fresh coffee cherry using huller, washing of pulp using a washer machine, then, the green beans were dried using oven at 40 $50^{\circ} \mathrm{C}$ to obtain green coffee with a constant weight or a constant moisture content of 10$12 \%$ using the 110 AMB Moisture balance tool. After the water content was reached, grinding process was done using Philips type HR2157.

Green coffee beans are processed further into roasting by a $20 \mathrm{~kg}$ capacity roaster with a temperature of $200-300^{\circ} \mathrm{C}$ for approximately 1 hour. Organics selected roasted coffee obtained from Ghalkoff while unselected roasted coffee is obtained from Coffee 49.

Chlorogenic acid testing using the LAAN-A-LC-E008 manual Shimadzu Application News No. L.306 and Agilent Application Note 2016, caffeine tested according to SNI 01-3542-2004 (6.6.A.2) for coffee powder and total phenolic content tested by spectrophotometer using Folin Ciocalteu reagents.

Testing and isolation of chlorogenic acid using a modification of the LAAN-A-LCE008 manual method Shimadzu Application News No. L.306 and Agilent Application Note 2016. The $0.2 \mathrm{~g}$ samples and $50 \mathrm{~mL}$ of deionized purified water from Milli-Q system (Millipore). The sample was placed in erlenmeyer and stored in the $100^{\circ} \mathrm{C}$ incubator for $10 \mathrm{~min}$. The sample was adjusted with aqua pure to $100 \mathrm{~mL}$ in a flask. The sample which is used for quantitative determination of chlorogenic acid and caffeine using HPLC was filtered with a syringe filter (pore size $0.45 \mu \mathrm{m}$, diameter $13 \mathrm{~mm}$ ). Each extraction and testing was carried out twice with less than 5\% difference. Chlorogenic acid and caffeine were tested by HPLC. Chlorogenic acid and caffeine were tested based on an external standard method with a concentration range of 5.10, 20, 40, and $60 \mathrm{ppm}$. The standard calibration curve was used to determine the correlation between signals measured from the area of the peak area and the concentration of the calculated sample. Retention time of UV absorption at maximum wavelength $273 \mathrm{~nm}$ for caffeine and 1 max $327 \mathrm{~nm}$ for chlorogenic acid. 
A $10 \mathrm{~mL}$ of both the standard solution and the sample test were injected into the HPLC (Shimadzu LC 20 AD) using a $50 \mathrm{~mL}$ syringe with the following conditions: column VP ODS C-18, 250x4.6 mm, mobile phase aquadest filter: acetonitrile: phosphate buffer (60:20:20), flow rate of $1 \mathrm{~mL} /$ minute, column temperature of $30^{\circ} \mathrm{C}$, PDA detector, running a mixture of standard caffeine and chlorogenic acid.

The polyphenol content was determined using the Folin Ciocalteu spectrophotometric method. Standard solution of gallic acid (10$100 \mathrm{ppm}$ ) was used to obtain a calibration curve. The content of polyphenol compounds is measured as a percentage of gram gallic acid equivalent per $100 \mathrm{~g}$ extract. The were two replications for each analysis.

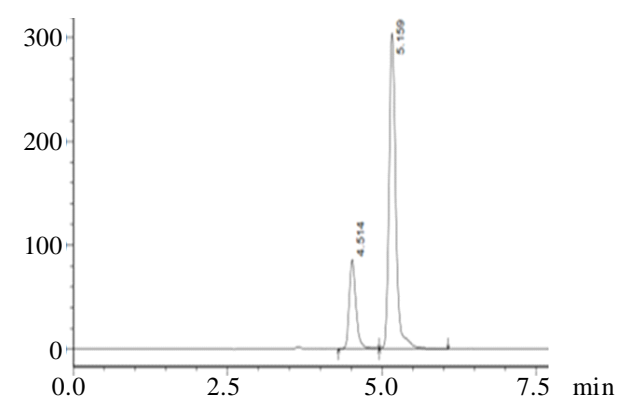

a. Chromatogram on $273 \mathrm{~nm}$

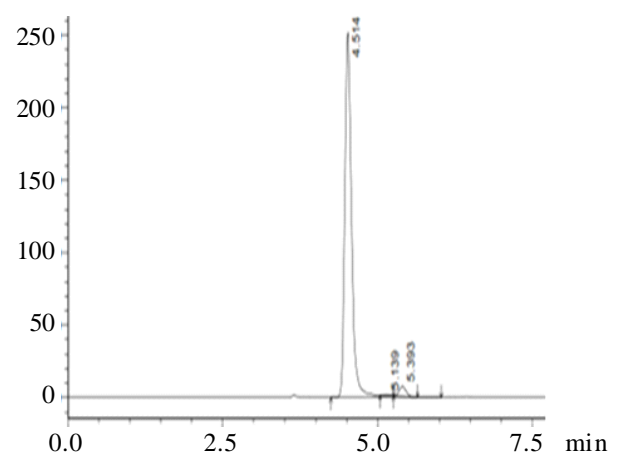

c. Chromatogram on $327 \mathrm{~nm}$

\section{RESULTS AND DISCUSSION}

Based on the chromatogram analysis (Figure 1), the maximum wavelength (l) for $40 \mathrm{ppm}$ caffeine standard solution was on 273 and $204 \mathrm{~nm}$ (a, b). In chromatogram and UV spectrum of caffein on $273 \mathrm{~nm}$, there were peaks which consisted of caffeine peak and chlorogenic acid peak. The appearance of chlorogenic acid peak looks similar to $40 \mathrm{ppm}$ chlorogenic acid standard solution chromatogram on maximum wavelength (l) (c). It indicates that the absorption area of chlorogenic acid is wide and appear on the wave length for detection of caffeine. While in reading the standard chlorogenic acid on lmax $372 \mathrm{~nm}$ peak from caffeine does not appear on retention time $=5.159(\mathrm{c}$ and $\mathrm{d})$.
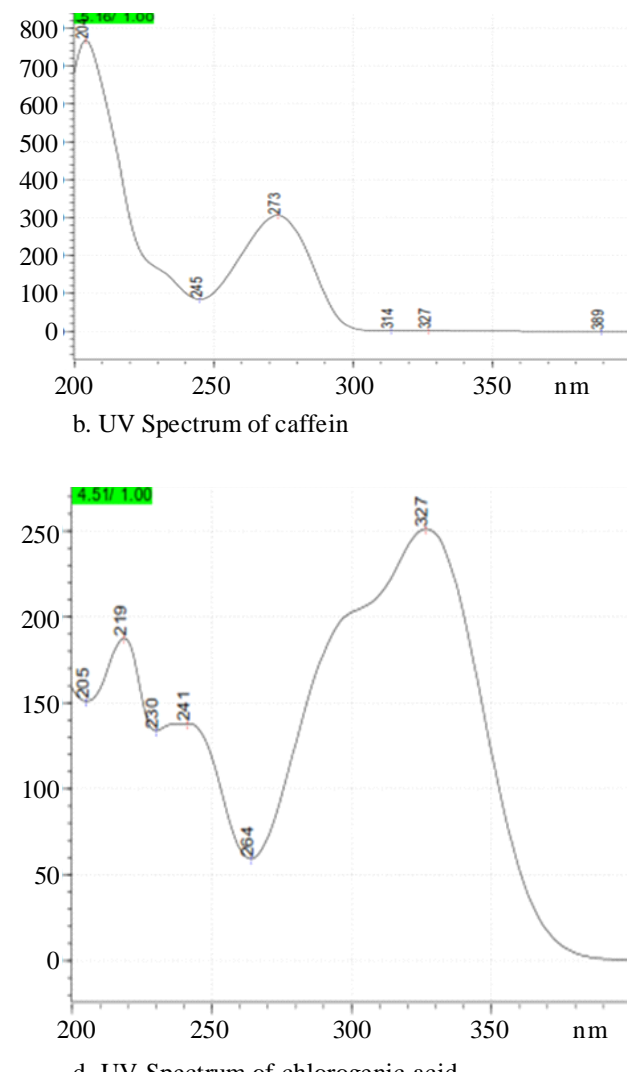

d. UV Spectrum of chlorogenic acid

Figure 1. HPLC Chromatogram (a and c) and UV spectrum and retention time (b and d) from chlorogenic acid and caffeine 
The main group of phenolic compounds is hydroxycinamic acid which is found in almost all plants. Phenolic compounds which are in the hydroxycinamic acid compounds group are insoluble compounds and bind to plant cell wall components. That cinnamic acid derivatives were identified as two intense bands as chlorogenic and caffeine acids with maximum absorption in regions 219 and $325 \mathrm{~nm}$ (Lee, 2000).

Chlorogenic acid content in selected coffee is higher than the unselected. There is no large difference of caffeine content in selected and unselected coffee. The effect of roasting decreases the chlorogenic acid substance both in selected and unselected coffee. The roasting changes the bean color become dark by Mailard reaction (Priftis et al., 2015). The roasting does not effect significantly on caffeine content. This is due to the effect of temperature on chlorogenic acid substance. Most of the chlorogenic acid become caffeine acid and quinic acid during roasting (Clifford, 1985; Aklimawati, 2014).

The caffeine and chlorogenic acid contents in coffee bean are higher than in parchment coffee. This finding may be used as the basic consideration for future research about coffee parchment utilization.

The potential antioxidant activity of plant materials depends on the content of phenolic compounds in the plants or extracts (Amarowicz $\&$ Pegg, 2019). Table 1 shows the total phenolic content, which calculated by linear regression method based on gallic acid standard solution (10-100 ppm). X represents the gallic acid standard solution, and $\mathrm{Y}$ is the absorbance.
The linear regression, the statistical calculations as a straight line equation $\mathrm{Y}=0.0107 \mathrm{x}$ $+0.0037\left(R^{2}=0.9999\right)$. The calculation of phenolic content is based on that equation. The total phenolic content of each sample before and after roasting of the two types of coffee shows differences as shown in Table 1. Total phenolic of unselected coffee content is higher than in selected coffee. It is assumed that phenolic compound in unselected coffee is due to the presence of other phenolic compounds besides chlorogenic acid. Chlorogenic acid is recoqnized classified an antioxidant while caffeine is classified as alkaloid that correlated with the quality of coffee roasted beverage (JeszkaSkowron et al., 2015; Patriche et al., 2015; Rothwell et al., 2014).

Roasting process does not have effect on the total of polyphenolic contents. The effect of temperature on green bean only decreases the chlorogenic acid content and is followed by an increase in caffeine content as if there is no effect on the total phenolic value. There are some process of chlorogenic acid during roasting, such as: isomerization, hydrolysis, and degradation into small molecular weight compounds (Amarowicz $\&$ Pegg, 2019).

Table 1 also describes the total polyphenolic contents in coffee green bean is higher than in parchment coffee. Extraction of chlorogenic acid and caffeine from the parchment coffee indicates the low content of active compounds which is inefficient to be extracted.

Table 1. Caffeine, chlorogenic acid, and total phenolic content

\begin{tabular}{lccc}
\hline Sample & Caffeine (anhydrous), $\%$ & Chlorogenic acid, \% & Total phenolic content, \% \\
\hline Roasted selected coffee & $2.32 \pm 0.02$ & $0.026 \pm 0.00$ & $3.54 \pm 0.00$ \\
Green bean selected coffee & $1.70 \pm 0.03$ & $4.41 \pm 0.27$ & $3.94 \pm 0.04$ \\
Parchment bean selected coffee & $0.71 \pm 0.00$ & $0.40 \pm 0.01$ & $1.83 \pm 0.01$ \\
Roasted unselected coffee & $2.42 \pm 0.02$ & $0.03 \pm 0.01$ & $4.74 \pm 0.00$ \\
Green bean unselected coffee & $2.02 \pm 0.02$ & $3.60 \pm 0.06$ & $5.21 \pm 0.06$ \\
\hline
\end{tabular}

Notes: Figures are means \pm standard deviation. 


\section{CONCLUSIONS}

The selection of coffee in harvest based on maturity have an effect on chlorogenic acid contents. The green bean selected coffee contains chlorogenic acid of $4.41 \%$, higher than the green bean unselected coffee. For the purpose of extracting chlorogenic acid, it is better to select the coffee, which means harvest only the ripe coffee or red cherry coffee. Caffeine contents in unselected coffee both in green bean and roasted (2.02-2.42\%) are higher then selected coffee, while total phenolic contents (3.94-5.21\%) tend to be lower if the coffee are roasted both in selected and unselected. The roasting decreases chlorogenic acid contents (about $0.026-0.3 \%$ ).

\section{ACKNOWLEDGEMENT}

We would like to express our gratitude to the Head of the Center for the Research and Standardization Industry in Bandar Lampung, Ministry of Industry, in supporting this research funding allocation for the 2018 National Priority; Prof. Tati Suhartati as Professor in Organic Chemistry Lampung University; Valentino and Mentari, for supporting the isolation and purification activities. Our gratitude also addressed to the Integrated HPLC Lab Instrumentation test laboratory at UPT LTSIT University of Lampung (Mr. Miftah) and Aneka Coffee Industry (Mr. Dian H and Mrs. Lily), and Kopi Ghalkoff (PT. GRI) for the supply of red cherry beans. Our gratitude to fellow colleagues for Structural Officials and Functional officials of Engineering Researchers at the Baristand Industri Bandar Lampung.

\section{REFERENCES}

Aklimawati. L.; Yusianto \& S. Mawardi (2014). Karakteristik mutu dan agribisnis kopi Robusta di lereng Gunung Tambora, Sumbawa. Pelita Perkebunan, 30, 159-180.
Amarowicz, R. \& R.B. Pegg (2019). Natural antioxidants of plant origin. Advances in Food and Nutrition Research, January, 1-81.

Clifford, M.N. (1985). Chlorogenic acids. p. 153-202. In: R.J. Clarke \& R. Macrae (Ed.). Coffee. Elsevier Applied Science, London.

Cuong,T.V.; L.H. Ling; G.K. Quan; T.D. Tiep; X. Nan; C.X. Qing \& T.L. Linh (2014), Effect on roasting conditions on several chemical constituents of Vietnam Robusta Coffee. The Annals of the University Dunarea de Jos of Galati Fascicle VIFood Technology, 38, 45-36.

Handayani, A. (2015) Evaluasi tingkat penanganan pascapanen kopi Robusta sesuai GMP (Good Manufacturer Practices): Studi kasus di Desa Wonokerto, Pringsurat, Kabupaten Temanggung. p. 109-116 In: Seminar Nasional Pangan Lokal, Bisnis, dan Eko-Industri Proceeding, Semarang, Indonesia.

Jeszka-Skowron, M.; A. Zgola-Grzeskowiak \& T. Grzeskowiak (2015). Analitycal methods applied for the characterization and the determination of bioactive compounds in coffee. European Food Research and Technology, 240, 19-31.

Jeszka-Skowron, M.; A. Sentkowska; K. Pyrzyn’ska $\&$ M.P.D. Peña (2016). Chlorogenic acids, caffeine content and antioxidant properties of green coffee extracts: influence of green coffee bean preparation. European Food Research and Technology, 242, 1403-409.

Kajikawa, M.; T. Maruhashi; T. Hidaka; Y. Nakano; S. Kurisu; T. Matsumoto; Y. Iwamoto; S. Kishimoto; S. Matsui, Y. Aibara: F.M. Yusoff; ; Y. Kihara; K. Chayama; C. Goto; K. Noma; A. Nakashima; T. Watanabe; H. Tone; M. Hibi; N. Osaki; Y. Katsuragi \& Y. Higashi (2019). Coffee with a high content of chlorogenic acids and low content of hydroxyhydroquinone improves postprandial endothelial disfunction in patients with borderline and stage 1 hypertension. European Journal of Nutrition, 58, 989-996.

Kouadio, I.A.; M.K. Koffi \& M.B. Dosso (2014). Effect of Robusta (Coffea canephora P.) 
coffee cherries storage after harvest before putting out for sun drying on development of toxigenic fungi and the variation of the physicochemical components. Food and Nutrition Sciences, 5, 117-126.

Lee, H. (2000). HPLC analysis of phenolic compound. p. 775-824. In: L. Noilet (Ed). Food analysis by HPLC. Marcel Dekker, New York.

Liang, N. \& D.D. Kitts (2016). Role of chlorogenic acids in controlling oxidative and inflammatory stress conditions. Nutrients, 8 , $1-20$.

Maalik, A.; S.M. Bukhari; A. Zaidi; K.H. Shah \& F.A. Khan (2016). Chlorogenic acid: a pharmacologically potent molecule. Acta Poloniac Pharmaceutica-Drug Research, 73, 851-854.

Naveed, M.; V. Hejazic; M. Abbasa; A.A. Kambohd; G.J. Khane; M. Shumzaid; F. Ahmad; D. Babazadehh; X. FangFang; F. ModarresiGhazani; L. WenHua \&Z. XiaoHui (2018). A pharmacological review and call for further research. Biomedicine \& Pharmacotherapy, 97, 67-74.

Priftis, A.; D. Stagos; K. Konstantinopoulos; C. Tsitsimpikou; D.A. Spandidos; A.M. Tsatsakis; M.N. Tzatzarakis \& D. Kouretas (2015). Comparison of antioxidant activity between green and roasted coffee beans using molecular methods. Molecular Medicine Report, 12, 7293-7302.

Patriche, S.; M. Boboc; V. Leah \& R-M. Dinica (2015). Extrction and evaluation of bioactive compounds with xtrantioxidant potential from green arabica coffee extract. The Annals of the University Dunarea de Jos of Galati Fascicle VIFood Technology, 39, 88-95.

Ramanda, E.; A.I. Hasyim; \& D.A.H. Lestari (2016). Analysis of competitiveness and quality of coffee Sumberjaya district in West Lampung. Jurnal Ilmu Ilmu Agribisnis, 4, 253-261.
Rothwell, J.A.; Y. Fillatre; J.-A. Martin; B. Lyan; E. Pujos-Guillot; L. Fezau; S. Harcberg; B. Comte; P. Galan; M. Touvier \& C. Manach (2014). New biomarkers of coffee consumption identified by the non-targeted metabolomic profilling of short study subjects. PloS ONE, 9, $1-11$.

Sudaryanto, A.; F. Wijayanti \& Carolina (2016). Introduksi teknologi pasca panen pada unit usaha mikro pengolahan kopi di Kabupaten Sumba Barat Daya NTT. p. 718-721. In: Prosiding Seminar Nasional IENACO-2016.

Tajik, N.; M. Tajik; I. Mack \& P. Enack (2017). The potential effects of chlorogenic acid, the main phenolic components in coffee, on health: a comprehensive review of the literature. European Journal of Nutrition, 7, 2215-2244.

Taveira, J.H.D.; S.D.V.F. Da Rossa; P.D. Oliveira; G.S. Giomo; E.P. Isquierdo \& V.A. Fortunato (2015). Post-harvest effects on beverage quality and physiological performance on coffee beans. African Journal of Agricultural Research, 10, 1457-1466.

Teniro, Y.W.;Zulfan \& Husaini (2018). Perkembangan pengolahan kopi Arabika Gayo mulai dari panen hingga pasca panen di kampong Simpang Teritit tahun 2010-2017. Jurnal Ilmiah Mahasiswa (JIM) Pendidikan Sejarah FKIP Unsyiah, 3, 52-63.

Sukohar, A. \& Muhartono (2015). Comparative effects of chlorogenic acid and doxorubic in against expression of caspase 3 in cell lines Hep-G2. Journal of Chemical and Pharmaceutical Research, 7, 187-92.

Wintgens, J.N. (2009). Coffee: Growing, Processing, Sunstainable Production (2 ${ }^{\text {nd }}$ Ed.). Wiley-VCH, Weinhem.

$* * 0 * *$ 